Historic, Archive Document

Do not assume content reflects current scientific knowledge, policies, or practices. 
Foreign PLANT QUARANTINES

Hirdy Herbaceous

and

Alpine Plomts

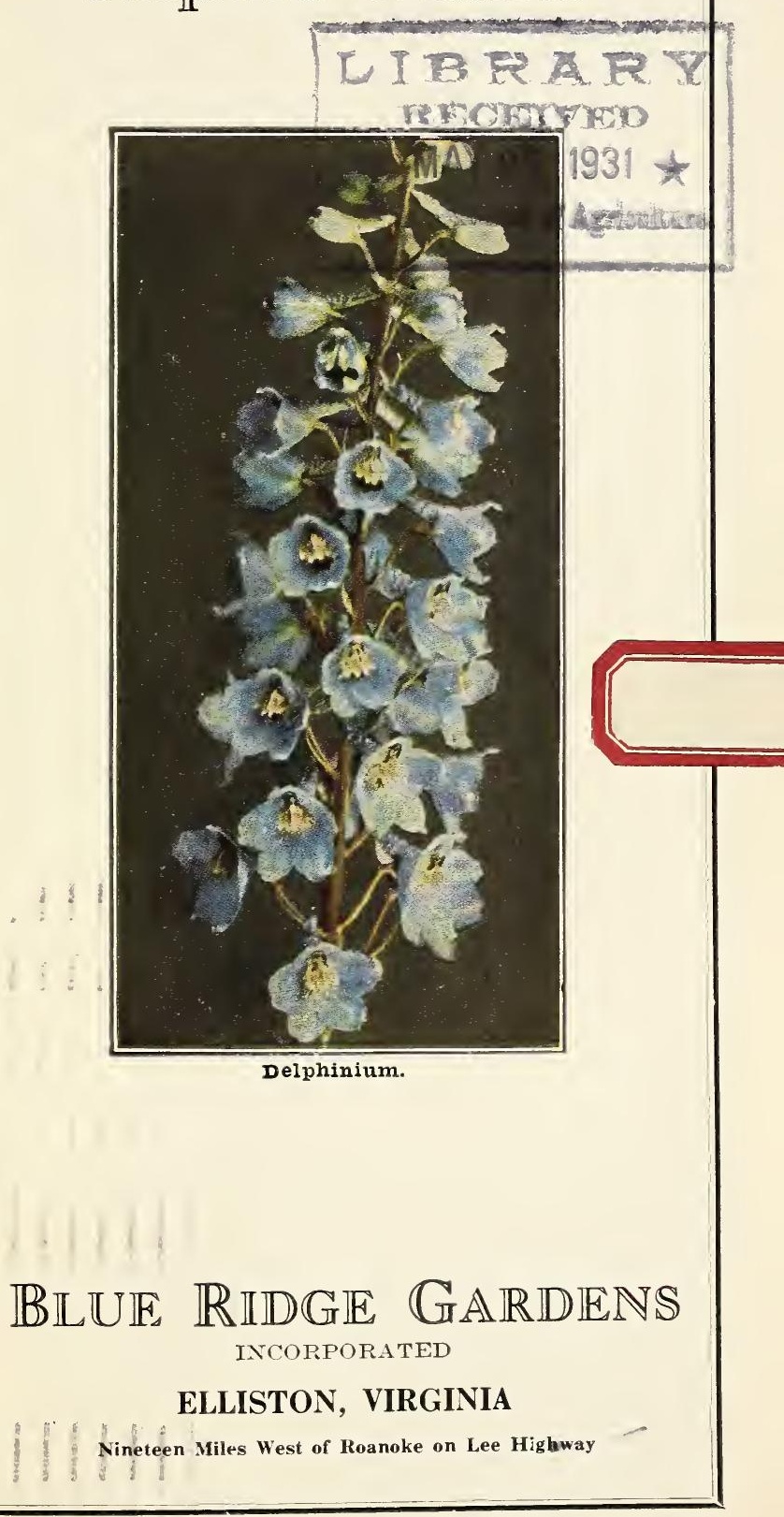




\title{
READ CAREFULLY
}

All of the stock offered is grown on our own grounds, that grown from cuttings and divisions we know to be clean and true. Plants grown from seeds are from seed stock obtained from the most reliable sources.

OUR PLANTS ARE ALL FIELD GROWN, ARE GIVEN CONSTANT CARE AND CULTIVATION AND WHEN SENT OUT ARE STRONG AND WELL DEVELOPED, MUCH LARGER AND WORTH A GREAT DEAL MORE MONEY THAN POT-GROWN PLANTS.

We do not divide our plants before shipping but send the entire plant as dug. Dividing is only done in rare cases and only then because it is necessary to get the best results.

\section{TERMS OF PAYMENT}

Customers unknown to us will please send cash or references with their order. It is impossible for us to make immediate shipment to new clients who do not send references or cheque with their order. NOT SENDING REFERENCES OR ENCLOSING CHEQUE CAUSES DELAY IN THE FORWARDING OF THE STOCK YOU ORDER.

\section{GUARANTEES}

We guarantee all stock furnished by us to be first class, true to name, large and healthy, all of a size so as to give IMMEDIATE RESULTS.

However, there are so many causes for failure over which we have no control that we can assume no responsibility after stock is delivered. Poor soil, unfavorable weather, ignorant or careless culture-all contribute to failure and are beyond our control.

If, after receiving, you are not satisfied with the quality of the stock, let us know and we will replace anything you mention without charge or without question.

\section{QUANTITIES ORDERED}

We do not sell less than three piants of a kind unless offered otherwise; twenty-five plants are sold at hundred rate.

\section{SHIPPING DIRECTIONS}

Please give explicit shipping directions, stating whether stock is to be shipped by freight or express, and by what route.

Small shipments can be sent by parcel post. All such shipments will be sent insured, insurance and postage to be paid by the customer.

\section{BLUE RIDGE GARDENS}

\author{
Elliston, Virginia
}




\section{Hardy Perennial Flowers}

Hardy perennials, that is those that stay out all winter, come again every spring and bloom more profusely than ever, offer to the average home owner an opportunity for flowers every week of the growing season.

While our list is not a large one it contains the most reliable varieties for the average "old fashioned border." Can you have a more enjoyable time than playing with your flowers? Is there any other phase of recreation that loolds for its followers such a peculiar charm? Gardening offers untold pleasures and undescribed satisf act on and the perennial border holds out in prospect, many pleasant minutes to those who choose to plant one.

\section{PLANTING SUGGESTIONS}

Distance-Ordinarily you plan to set perennials 18 inches apart. For the dwarf varieties 15 inches. If you will block off your border in squares you will quickly ascertain your requirements and in planting vary, of course, from the rigid lines, but try to alternate them as the effect is better.

Grouping-Try to arrange them in groups of three or more of a variety, depending on the size of your border. If you scatter one here and there the effect is not so good. Peonies and Iris develop into large plants and should be planted singly except in large borders. The size of growth is given and with the taller ones in the back ground the planning is easy.

After Care-For the sake of neatness and to conserve the vitality of the plants the blossom or seed spikes should be removed immediately after blooming, leaving, of course, foliage sufficient to carry on the natural functions of the plant.

Mulching for winter protection is suggested. It should be applied late, that is, November and December. It should not be put on too heavy as it will smother the plants. Plants with green foliage and soft crowns should not be covered, but rather have the mulch pulled up about them.

Fertilizing is necessary and the application of well rotted manure is suggested as it not only stimulates growth but improves the physical condition of the soil. Bone meal is advised for Peonies and Delphinium, especially.

Replanting-You will find it advantageous to break up old plants periodically, as they seem to get sluggish if left too long. Young plants seem to have more vigor. When plants get to "slowing up," then divide them and they will do better.

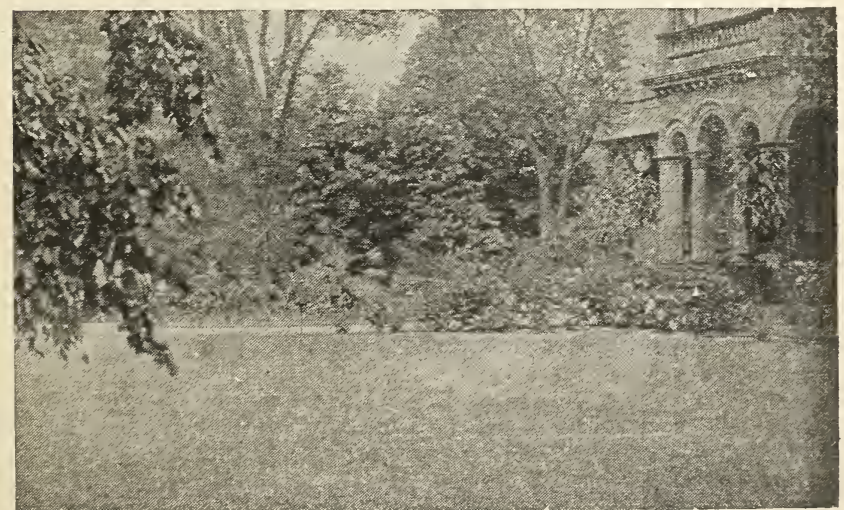




\section{ANCHUSA ITALICA}

"Dropmore" variety-A fine, large, hardy, herbaceous plant; 4 to 5 feet high. This new "Dropmore" variety is a great improvement on the type, the beautiful Forget-Me-Not-like flowers being much larger than others and of a lovely Gentian blue, produced in long, loose sprays. Invaluable for the hardy border, as flowers are produced during the entire season and until late in the fall. $25 \mathrm{c}$ each or $\$ 2.00$ dozen.

\section{ACHILLEA (Milfoil or Yarrow).}

Plants suitable for dry sunny places. The dwarf kinds are useful for carpeting or for rockeries; the taller varieties as border plants.

Ptarmica, Boule de Neige-New. An improvement on "The Pearl," with fuller and more perfect flowers. Best for borders.

Millefolium roseum (Rosy Milfoil)-July to October. Rosy pink flowers in dense heads, on stems 18 inches high. Effective on edge of shrubbery or in border.

25 c each or $\$ 2.00$ dozen.

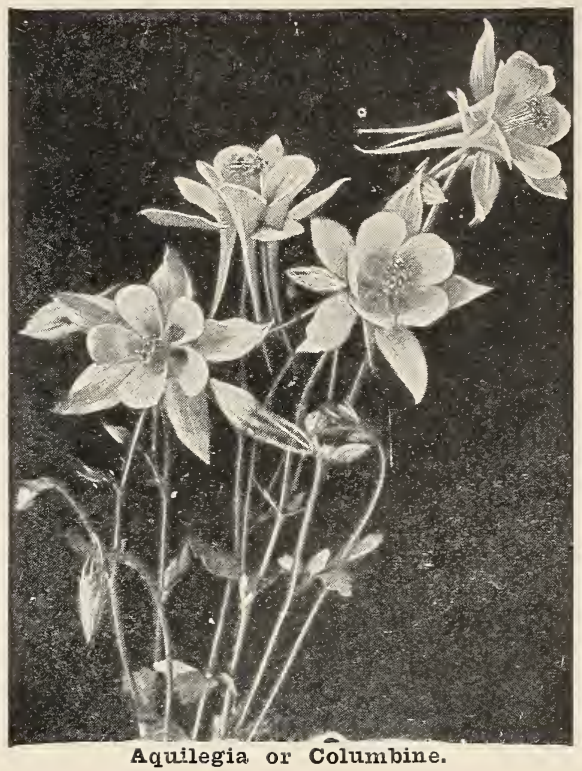

\section{AQUILEGIA OR COLUMBINE}

Aquilegias or Columbines are among the most beautiful of hardy spring and early summer flowers, and unlike many perennials the best varieties are produced from seed. They are very effective when grown in the herbaceous border and make charming specimens for vases and table decorations.

The Aquilegias have acquired much of their popularity on account of their adaptability to all soils and conditions, as they thrive happily even on very poor soil.

They are also valuable because their blooming period stretches over a time when there is likely to be a short lapse of bloom in most gardens, which is immediately after the spring bulbs are through flowering, and before the majority of perennials have begun.

The Aquilegias are fitting and desirable companions to grow with the Pyrethrum or Painter Daisy which blooms at the same time.

Mrs. Scott Elliott's Strain-This is probably the best strain of long spurred hybrids. The flowers are of rich and varied colors. 2-3 ft. May-June. 25c each or $\$ 2.00$ dozen. 


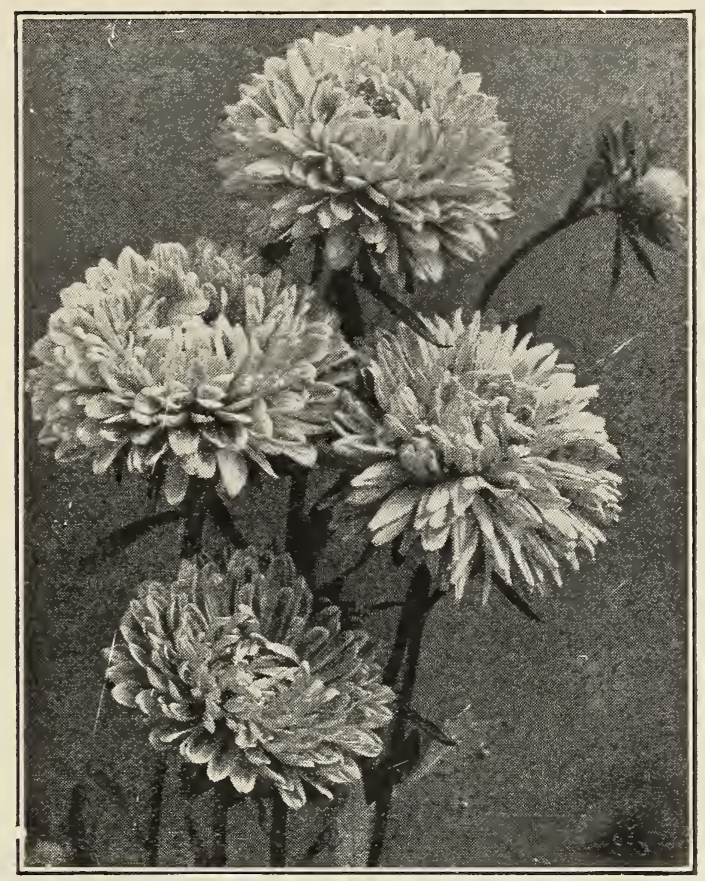

Hardy Asters.

HARDY ASTERS (Michaelmas Daisies).

The many species, widely distinct from each other in habit and form, are, with a few exceptions, all native of North America. It is in Europe, however, that our Asters have been most highly appreciated. Many improvements have been made by European growers, and many hybrid forms have been produced by crossing the different species. For the best results, they require division and replanting every third year.

Felthan Blue-A pretty aniline-blue, very free.

Novae-angliae roseum superbum-This is a new introduction of our own, and is by far the best Aster we have ever seen. Color almost red and a profuse bloomer.

St. Egwin-Clear rose pink, good habit. $3 \frac{1}{2} \mathrm{ft}$.

Climax-Large, pale mauve flowers with yellow centers, are borne on long slenter stems. 4-5 ft. September-October.

$25 \mathrm{c}$ each or $\$ 2.00$ dozen.

\section{BOLTONIA (False Chamomile).}

A showy native hardy perennial plant with large, single Aster-like flowers; in bloom during the Summer and Autumn months, and with its thousands of flowers open at one time produces a very showy effect.

Latisquama-Pink, slighty tinged with lavender. 4 to 6 feet. 25 c each or $\$ 2.00$ dozen.

\section{CAMPANULA MEDIUM (Canterbury Bells).}

These imposing herbaceous hardy biennials are profusely covered with large, bell-shaped flowers; extremely showy in shrubberies and mixed borders. Height 3 feet. Plants potted in October make most beautiful plants for the conservatory and greenhouse in the Spring, coming into flower, without being forced in any way, about two months before those in open ground. $25 \mathrm{c}$ each or $\$ 2.00$ dozen. 


\section{CHRYSANTHEMUMS}

Five extremely hardy varieties. Sorts that hold their foliage despite severe weather. Selected from fifty so called "hardy Chrysanthemums." All these varieties are well adapted as to cut flowers.

Autumn Glow-Rose-crimson; large.

Excelsior-Large, yellow.

Golden Queen-Golden yellow.

Pink Dandy-Silvery pink. Aster type. Flowers about two inches across or size of a silver dollar. When fully open flowers show a pretty yellow center. Foliage robust and large. Does best out doors but not well adapted for indoor forcing. Free bloomer. Midseason.

\section{Victory-Pure white.}

25 c each or $\$ 2.00$ dozen.

\section{CHRYSANTHEMUIM MAXIMUM (Shasta Daisy).}

The improved varieties of Marguerite, all allied to the Shasta Daisy that adorns our fields in the Spring, are among the most useful of our garden flowers. Not only have these flowers been greatly improved in size and form, but there are now early and late blooming varieties which give a succession of long-stemmed flowers so valuable for vase decoration during four months of the year.

Arcticum (The Arctic Daisy)-Among fall-flowering perennials this is a perfect gem. - It forms an attractive rosette-like clump of pretty dark green foliage, and in Sept mber multitudes of flower stems appear, terminated by pure white flowers 2 to $2 \frac{1}{2}$ inches in diameter. These begin to develop during the last week in September, and continue in good condition throughout October, and frequently into November.

Leucanthemum flore pleno (Double White Shasta Daisy)Flowers double pure white of medium size, excellent for cutting; each plant produces from 30 to 50 flowers; perfectly hardy without any protection. Our latest and best addition to the Shasta Daisies.

25 c each or $\$ 2.00$ dozen.

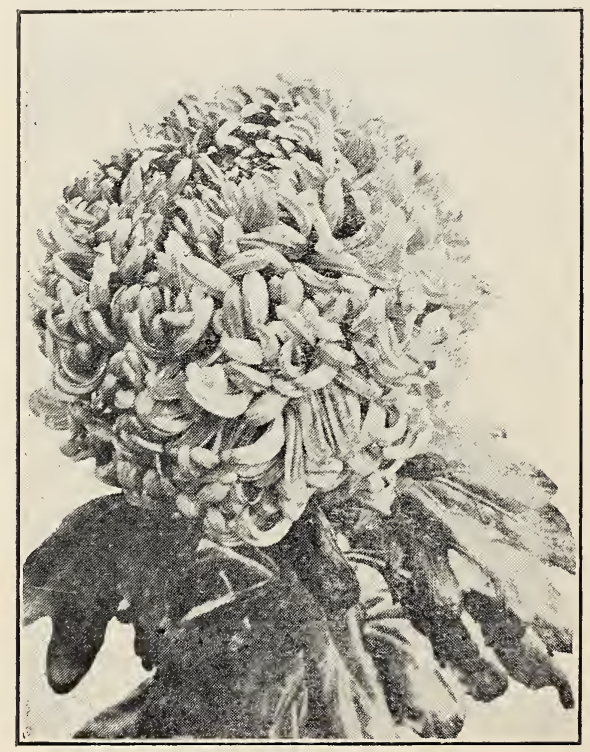

Chrysanthemums. 


\section{DELPHINIUM (Larkspur).}

These stately flowers differ from all others in their appealing charm. The rare beauty of their varying shades that range through white and turquoise blue to the deepest indigo and violet would add glory to any garden.

Light Blue, Belladonna-The praises of this variety have been sung by every lover of the hardy border. Light turquoise blue flowers are borne in spikes, the first coming in June. These may be cut away and young growth will start from the crown, producing blossoms all summer. Height 3-4 feet. Mulch lightly, as crown sometimes rots in winter.

Dark Blue. Bellamosum-This is an improved dark blue with all the other characteristics of the preceding. 3 feet. June to September.

English Hybrids-These are taller growing, being 4-5 feet and in all shades of light and dark blue. June to September.

25 c each or $\$ 2.00$ dozen.

\section{GIANT SHIRLEY FOXGLOVES}

We now have a fine lot of field-grown plants of the Giant Shirley Foxgloves. They are a genuine "Shirley" production of extraordinary size and vigor, growing 5 to 6 feet tall. The flower-heads are over 3 feet long, crowded with big, bell-shaped blossoms. Colors range from white and shell-pink to deepest rose, many attractively dotted with crimson or chocolate. Furthermore, they are more apt to be of perennial habit than the old-fashioned Foxgloves. 25c each or $\$ 2.00$ dozen.

\section{DIANTHUS, HARDY GRASS OR SPICE PINKS}

\section{(Double-Flowering Varieties)}

Dwarf, Large, Double-flowering Grass or Spice Pinks. (Dianthus Plumarius nanus, fl. pl.)-These are great improvements over the charming time-honored inhabitant of the oldfashioned gardens. The flowers are large and have a large variety of colors and markings; the color, of course, refers to the center of the flower, the remainder being white or blush with a band of color near the margin; the colors include bloodred rose, maroon, purple, pink, blush, spotted, laced, variegated, etc. They are excellent perennial garden plants, about 1 foot high, vigorous, hardy, and fiower profusely during spring and early summer. The flowers are beautifully fringed and emit a clove-likè perfume.

25 c each or $\$ 2.00$ dozen.

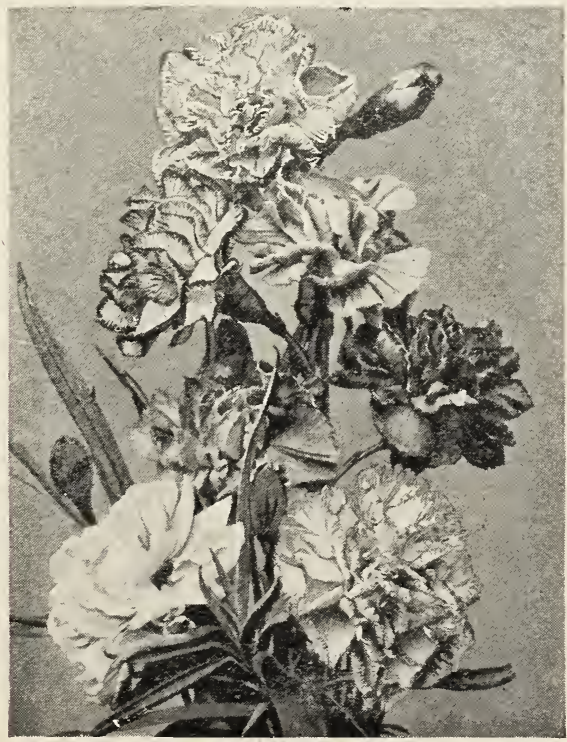

Dianthus. 


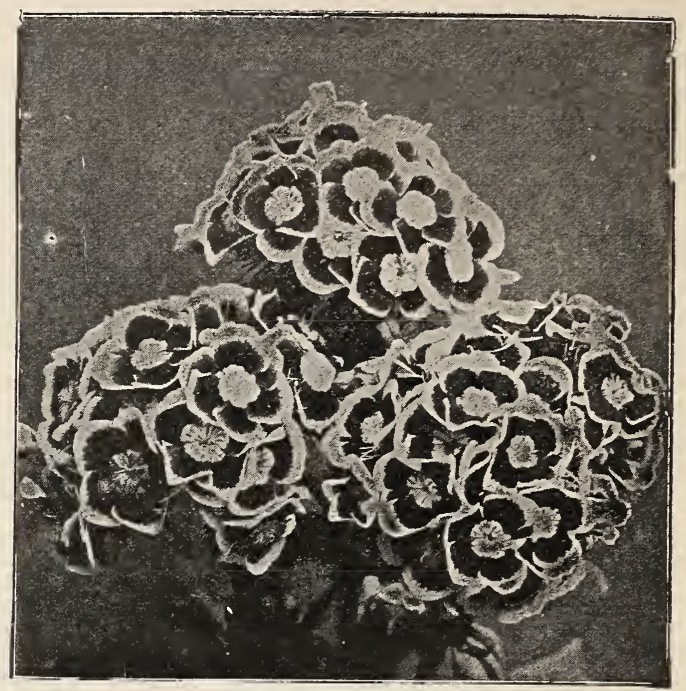

Sweet William.

DIANTHUS BARBATUS (Sweet William).

The Sweet William is a fine plant which produces great masses of bloom of extremely rich and varied colors. The flowers are lasting and fine for cutting.

Sweet William, Double Red.

Sweet William, White.

Sweet William, Newport Pink.

$25 \mathrm{c}$ each or $\$ 2.00$ dozen.

\section{GYPSOPHILA (Baby's Breath).}

Very branching or spreading, slender plants, with scant foliage when in bloom. Of easiest culture in open, rather dry places. Desirable where a mass of delicate, misty bloom will fill in a bare place.

Paniculata compacta - When in bloom in August and September it forms a symmetrical mass 2 to 3 feet in height and as much through, of minute white flowers having a beautiful gauzelike appearance.

Paniculata flore pleno-A light and graceful cut flower, compatible with all others, no matter of what shape or color; masses of minute double white flowers. (Plants offered are grafted, and we guarantee all plants sold to be double).

25 c each or $\$ 2.00$ dozen.

\section{EUPATORIUM (Hardy Ageratum).}

A splendid native plant, growing 6 to 10 inches high; immense heads of purplish pink flowers; fine for naturalizing along streams and ponds, and for planting among shrubbery.

Coelestinum-Lavender flowers. August to frost. $\$ 2.00 \mathrm{doz}$.

\section{HEMEROCALLIS (Yellow Day Lily).}

Hemerocallis have long been favorites in our garden, and are always included in any list of the most popular hardy plants. All of the varieties of Hemerocallis are desirable and beautiful. The tall, graceful, grasslike foliage is very handsome and sets off the charming lily-like flowers very effectively. They look particularly well naturalized along streams or on moist banks, and will thrive most luxuriantly in shade.

Flava (Lemon Lily)-Sweet scented, clear, full yellow; $21 / 2$ feet. Flowers in June.

Thunbergi-Much like Flava, but flowers in July, a month latter, and 6 to 10 inches of the upper portion of the flower scapes are thickened and flattened.

25 c each or $\$ 2.00$ dozen. 


\section{HELENIUM (Sneezewort).}

Tall growing plants closely allied to the Sunflower; bearing in late Summer and Fall great masses of large, daisy-like flowers in shades of yellow and orange.

\section{HOLLYHOCKS}

No hardy garden is complete without these stately plants. Their colossal spikes of bloom, 6 to 8 feet high, produce a bold effect that cannot be secured in any other way, when mingled among the shrubs, in the background of the hardy border, or in specimen clumps. Universal favorites everywhere.

Double-In separate colors. White, Rose, Crimson, Yellow, etc.

\section{Mixed Double.}

Mixed Single.

25 c each or $\$ 2.00$ dozen.

\section{LATHYRUS (Everlasting Sweet Pea).}

Latifolius-These Everlasting Peas are but little known in this country, but are great favorites in England. They are extremely showy and fine. Charming ciimbers for covering trellises, arbors, etc.

Mixed colors, $\$ 2.00$ dozen.

\section{LINUM (Flax).}

A desirable plant for the border or rockery, growing 2 feet high, with light, graceful foliage and large flowers all Summer.

Perenne-Very attractive, both in foliage and bloom. Flowers beautiful pale blue on slender, graceful stems. $\$ 2.00$ dozen.

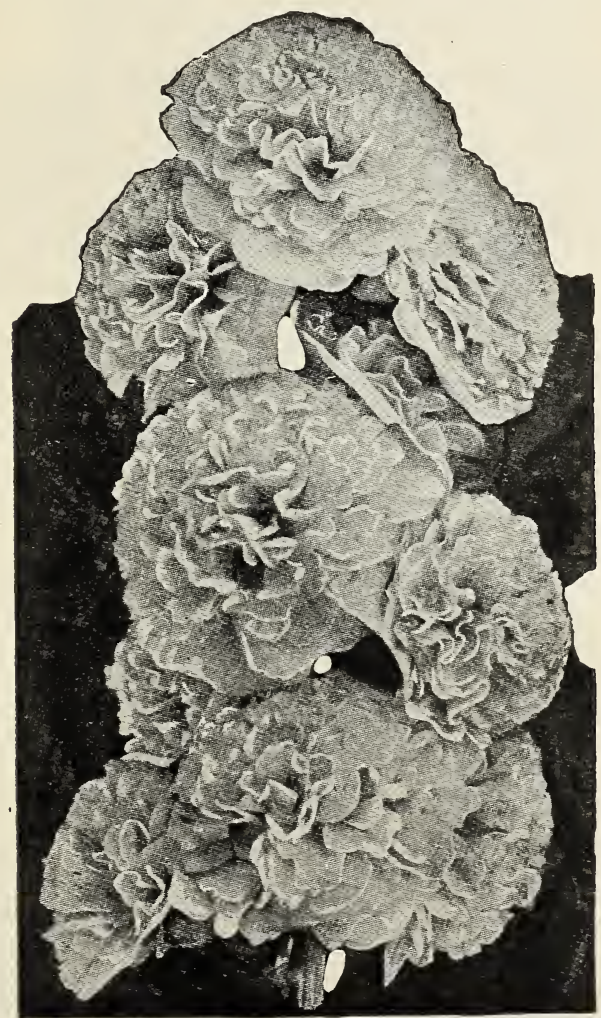

Double Hollyhocks. 


\section{GAILLARDIA (Blanket Flower)}

Improved English Strain-We consider the Gaillardia one of the most desirable hardy plants in cultivation, and our strain of these brilliant flowered plants to be the finest extant. Though such an ornamental addition to the herbaceous border, the perennial Gaillardia is content with extremely simple treatment. Dig the soil deeply and enrich with well-rotted manure. We recommend the Gaillardia for bedding purposes as well as for borders. Everyone will have noticed how grandly Gaillardias have thriven through droughts; they seem hardly to need water. The gay blossoms are obtainable in perpetual profusion from June to November and the greater the drought and scarcity of other flowers the more the utility of the perennial - Gaillardia is demonstrated. No more beautiful and brilliant sight can be imagined than a large bed of Gaillardias, with their profusion of highly colored flowers of all shades. Some of the varieties of our improved strain measure fully 5 inches in diameter. Choicest mixed colors. $\$ 2.00$ dozen.

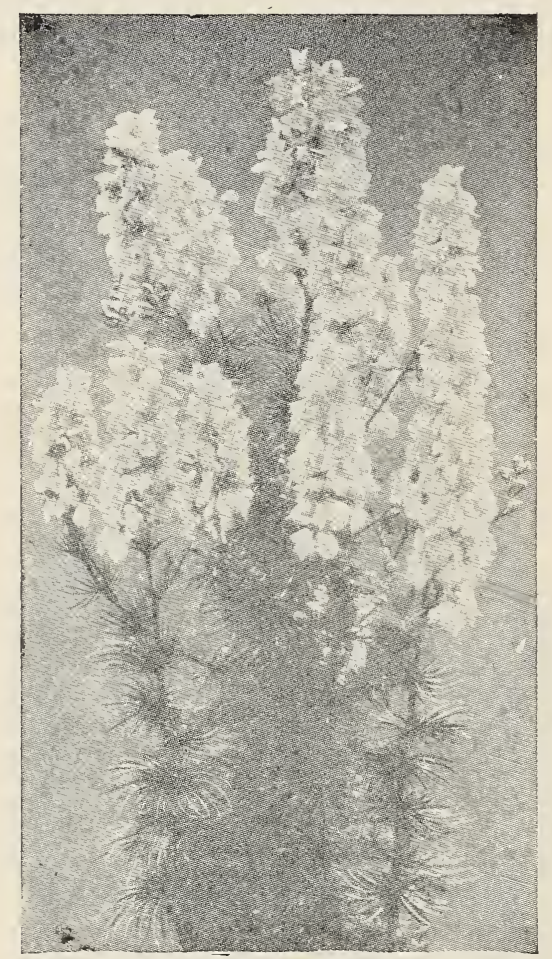

Iupines.

\section{LUPINUS (Lupines).}

The Lupines produce beautiful long spikes of pea-shaped flowers a foot long on stems three feet high. They are perfectly hardy but cannot endure drought, and must be planted in well prepared garden soil and kept watered in dry weather.

Polyphyllus (Hardy Lupin)-Clear blue. 3 to 4 feet. June to September.

Polyphyllus roseus-A splendid new variety, with flowers of beautifully shaded rose.

25 c each or $\$ 2.00$ dozen. 


\section{HIBISCUS (Mallow).}

A very showy plant for any position, but succeeds especially well in damp places. Very large, single, hollyhock-like flowers produced during the entire summer.

Crimson Eye-Flowers of immense size; pure white, with a large spot of deep velvety crimson in the center.

New Giant-Flowering (Mallow Marvels)-Wonderfully improved new varieties, wiith the richest colors and enormous flowers frequently 8 to 12 inches in diameter. Thrive in dry or wet ground. Perfectly hardy. In separate colors, Pink or White, 40 cts. each; Crimson, 50 cts. each; Mixed Seedlings, 30 cts. each.

\section{IRIS KAEMPFERI (Japanese Iris).}

The magnificent Iris Kaempferi belong to the Apogons, and a field of them in bloom is a most gorgeous sight. Seeing them for the first time, one cannot withhold an exclamation of surprise, and having once seen can never forget their striking beauty.

Culture---The secret of success is to keep the ground well stirred, never allowing it to bake or become hard. Any good mellow clay loam will grow Japanese Irises to perfection, if well enriched. They like plenty of moisture during the growing season, but flooding with water is not a necessity, as many suppose. Water standing over the plants for a great length of time in winter is fatal to them.

Time to Plant-Latter part of August to the beginning of October is the best time. Late plantings should be protected by a light covering of straw or leaves after the ground is permanently frozen, to prevent roots from being heaved out of ground by frost. In northern sections late planting had best be deferred until Spring. Mixed colors, $2 \check{c}$ each or $\$ 2.50$ dozen.

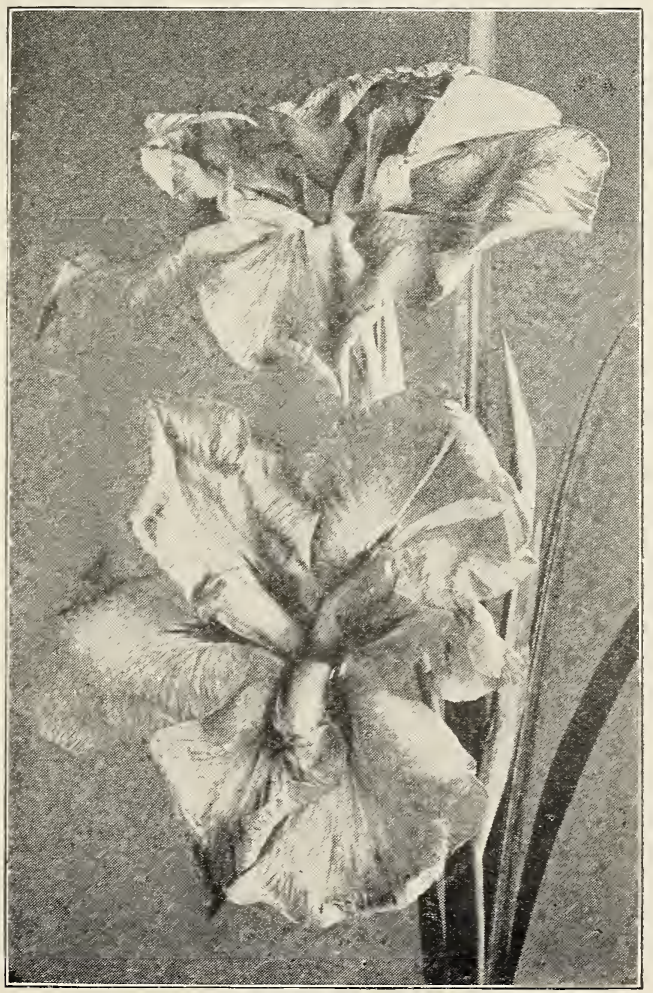

Japan Iris. 


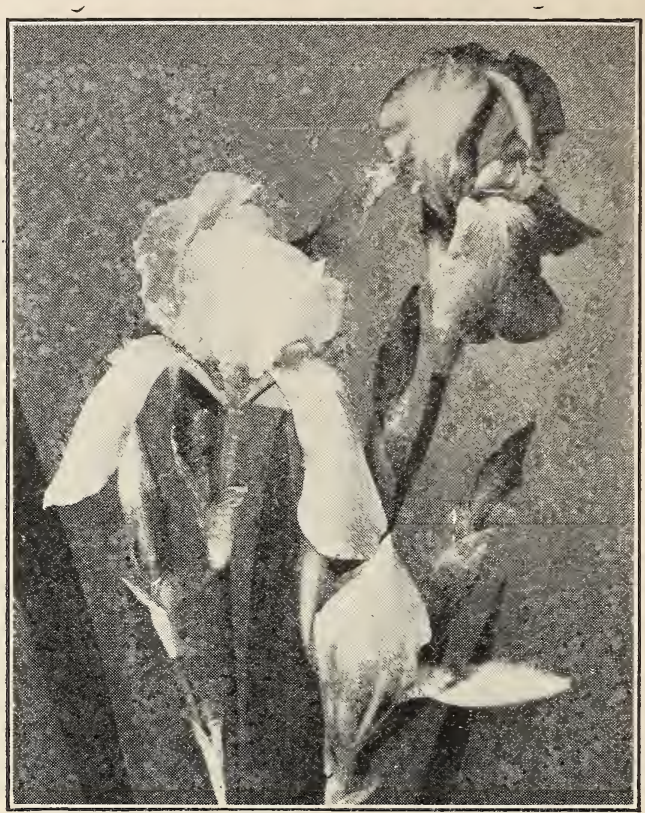

\section{German Iris.}

\section{IRIS GERIMANICA (German or Flag Iris).}

The Iris is one of the finest, if not the finest, of our hardy plants. Not particular as to soil or location, but asking only that the sun shine on it. It throws up spikes of bloom that are marvelous in their delicacy of structure and the colorings which are exquisitely dainty are wonderful in their. blendings and variety.

They are very effective planted in groups and if used for borders are particularly desirable in that the foliage remains fresh and upright after the blossom stalks are removed.

Plant in late August or early September preferably. Spring will do also.

The roots offered in this list are from plants transplanted a year ago and are of a size large enough to bloom next Spring. The collection is up to date and consists of the best and newest standard varieties.

The inches mentioned is the approximate height of the flower stem. The standards are the upright, the falls the drooping petals. Irises packed free. 25 of a kind at 100 rate.

Caprice-Cerise, deeper falls; early; 24 in. in.

Celeste-Azure blue, slightly deeper falls; midseason; 30

Crimson King-Rich claret purple; 24 in. 24 in.

Dr. Bernice-Coppery bronze, falls velvety crimson; large;

Eldorado-Standards bronze-yellow, falls bronze-purple; midseason; 30 in.

Honorabilis-Golden yellow and crimson brown; 18 in.

Juniata-Large; clear blue; very tall.

All above Iris $25 \mathrm{c}$ each or $\$ 2.00$ dozen. 
Khedive--Beautiful soft lavender; $30 \mathrm{in.}$

Monsig 1or-Standards violet, falls purple-crimson; late; 2 feet.

Orientalis Blue--Deep blue; late; 24 in.

Pallida speciosa-Large; purple; tall.

Perfection-Standards light blue, falls velvety violet-black.

Queen of May-Lilac pink; large; midseason; $32 \mathrm{in.}$

Speciosa-Lavender purple and reddish purple.

Walhalla-Standards light violet, falls deep purple; early; very large; 24 in.

All above Iris $25 \mathrm{c}$ each or $\$ \$ 2.50$. dozen.

Japan Iris-25c each or $\$ 2.00$ dozen.

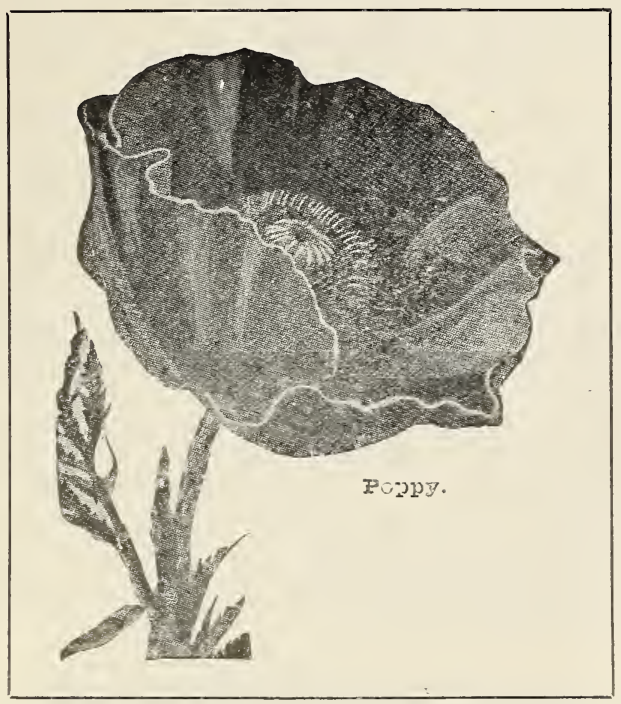

\section{POPPIES}

These are Oriental Poppies, vivid shade of red, blooming with the peonies, and the joy and admiration of everyone. Plant a few of our division and have flowers the first scason. 2 to 3 feet. We advise fall planting only. $25 \mathrm{c}$ each or $\$ 2.00$ doz.

\section{PLATYCODON (Japanses Bellflower).}

This comes in blue and white. Blossoming in July, the attractive flowers, often three inches across, come in succession for several weeks. Height $2 \frac{1}{2}$ to 3 feet. $25 \mathrm{c}$ each or $\$ 2.00$ doz.

\section{RUDBECRIA (Golden Glow).}

A yellow blooming perennial, that has become popular in a very short time since being introduced. The flowers in July and August are like small Chrysanthemums borne on the terminals of 5 to 6 foot stalks. Very desirable.

- Purpurea (Giant Purple Coneflower)-Peculiar reddish purple flowers, with a very large, brown, cone-shaped center. Blooms from July to October. 3 feet. $25 \mathrm{c}$ each or $\$ 2.00$ doz. 


\section{PHLOX DECUSSATA (Hardy Phlox).}

Perennial Phloxes succeed in almost any soil enriched with manure in Spring and in hot weather an occasional soaking of water. If the first spikes of bloom are removed as soon as over, they will produce a second supply of flowers, continuing the display until late in Autumn. These later blooms are often f ner than the first. (We offer nothing but strong, 2-year-old plants).

Athis-Deep, clear salmon. Very fine.

Coquelicot-A fine scarlet.

Eclaireur-Bright carmine with light halo. Large flower.

Elizabeth Campbell-Bright salmon-pink, with lighter shadings and dark red eye; one of the handsomest and most attractive.

Ferdinand Cortez-Deep crimson.

Isabey-Salmon pink.

Lothair-Bright crimson.

Michael Buchner-Lavender.

Miss Lingard-The best Phlox in cultivation. It produces immense heads of beautiful white flowers in June and blooms again in September and October. Splendid foliage and habit, and free from attacks of red spider. Better results will be had if old flowers are cut off.

Mme. Prosper Langier-Fine dark red.

Mrs. Ethel Prichard-Rose-mauve.

Mrs. Jenkins-White; immense panicles; free bloomer.

Mrs. Scholten-New. Dark salmon-pink flowers in enormous pyramidal spikes.

Rijnstroom-New. Immense trusses, with blooms larger than a silver dollar. Beautiful, clear pink. Extra fine.

Siebold-Large trusses of fiery orange-scarlet flowers with crimson center.

Sir Edwin Landseer-Bright crimson.

Von Hochberg-Brilliant red.

25 c each or $\$ 2.00$ dozen.

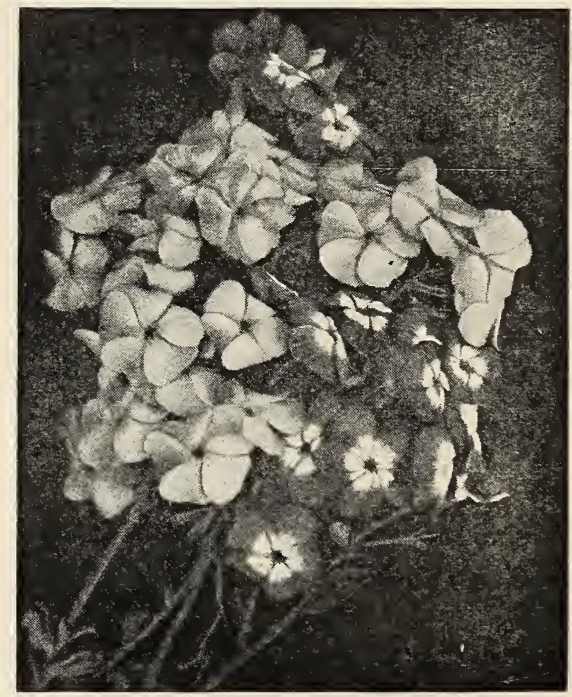

Hardy Phlox. 


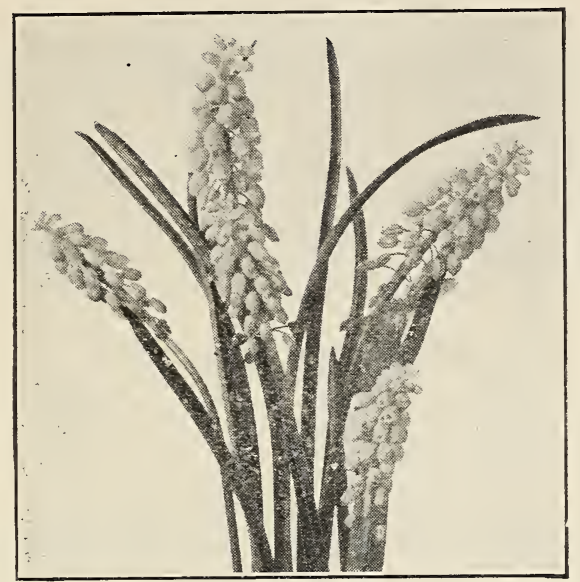

Tritoma.

YUCCA FILAMENTOSA (Adams Needle).

One of the hardiest and showiest plants we have. The flower spikes are borne in huge panicles above the swordshaped foliage which in itself has a sub-tropical effect. The large, white, waxy blooms are drooping in habit, and the plant, whether in bloom or not, presents a highly ornamental effect. It can be used to advantage in any situation. Price $50 \mathrm{c}$ each; $\$ 5.00$ doz.

\section{SEDUM (Stonecrop).}

Dwarf Varieties-America's greatest rock plant. Suitable for the rockey carpet-bedding, covering of graves, etc.

Acre (Golden Moss)-Much used for covering graves; foliage green; flowers bright yellow.

Asiaticum-Yellow flowers, blooming in July and August: 1 foot.

Erect-Growing Varieties-Useful and pretty plants for the border, producing the interesting flowers during late Summer and Fall.

Spectabile-One of the prettiest erect-growing species, attaining a height of 18 inches, with broad, light green foliage and immense heads of handsome, showy rose colored flowers; indispensable as a late Fall-blooming plant.

Spectabile "Brilliant"-A rich colored form of the preceding, being a bright amaranth-red.

$25 \mathrm{c}$ each or $\$ 2.00$ dozen.

\section{TRITOMA (Red Hot Poker; Flame Flower; Torch Lily).}

Pfitzeri (The Everblooming Flame Flower)-The free and continuous blooming qualities of this variety have made it one of the great bedding plants, and when we consider that there are few flowering plants which are suitable for massing under our severe climatic conditions it is little wonder that such an elegant subject should become so popular. Succeeds in any ordinary garden soil, but responds quickly to liberal treatment. Hardy if given protection, but the most satisfactory method of Wintering is to bury the roots in sand in a cool cellar. In bloom from August to October, with spikes 3 to 4 feet high, and heads of bloom of a rich orange-scarlet producing a grand effect either planted singly in the border or in masses. 25c each; $\$ 2.50$ dozen. 


\section{VERONICA (Speedwell).}

A family containing some of the most beautiful subjects for the hardy garden and rockery. Given a rich, well drained soil in an open situation in full sun, they will all thrive in an amazing manner.

Longifolia subsessilis--2 feet. July to September. One of the handsomest blue-flowering plants. Perfectly hardy and increases in strength and beauty each year. Spikes completely studded with beautiful blue flowers; fine for cutting and one of the best plants for the hardy border. 25c each; $\$ 2.00$ per dozen.

\section{ORNAMENTAL GRASSES}

Much used for planting as single specimens on the lawn or in groups and beds. Nothing gives a finer effect than strong clumps of these grasses well placed.

Elymus glaucus (Blue Lime Grass)-Handsome grass with narrow glaucous silvery foliage. Well adapted for the border or edge of beds with taller sorts. $35 \mathrm{c}$ each; $\$ 3.00$ dozen.

Erianthus ravennae (Plume Grass or Hardy Pampas)-10 to 12 feet high, frequently throwing up 30 to 50 flower spikes. Closely resembles Pampas Grass. 50c each; $\$ 4.50$ dozen.

Eulalia gracillima univittata (Japan Rush)-Graceful habit, with very narrow foliage; of a bright green color, with a silvery midrib. 6 to 7 feet. $25 \mathrm{c}$ each; $\$ 2.50$ dozen.

Eualia japonica-Long, narrow, graceful green foliage, and when in flower the attractive plumes are 6 to 7 feet high. $25 \mathrm{c}$ each; $\$ 2.50$ dozen.

Eulalia japonica variegata-Very ornamental; long, narrow leaves, striped green, white, and often pink or yellow. $35 \mathrm{c}$ each; $\$ 3.00$ dozen.

Eulalia japonica zebrina (Zebra Grass)-The long blades of this variety are marked with broad, yellow bands across the leaf. It makes a very attractive specimen plant for the lawn. 6 to 10 feet. $35 \mathrm{c}$ each; $\$ 3.00$ dozen.

Festuca glauca (Blue Fescue Grass)-12 to 15 inches. Ornamental grass. Grown for dense tufts of very narrow bluish leaves. Used for edgings or for contrast with darker foliage. Desirable for rock garden. 25c each; $\$ 2.50$ dozen.

Pennisetum japonicum (Fountain Grass)-A beatiful grass whose flower heads are produced in the greatest profusion. Color rich mahogany, conspicuously tipped with white. $35 \mathrm{c}$ each; $\$ 3.00$ dozen.

Phalaris arundinacea variegata (Variegated Ribbon Grass) -Leaves longitudinally striped white; very ornamental; sometimes run wild about old places. 18 inches. $25 \mathrm{c}$ each; $\$ 2.50$ dozen.

We can supply old English dwarf boxwood, two to ten foot spread. Single specimens or car lots. List on request.

\section{Vinca Minor (Periwinkle)-Ever-} green; ground cover.

25 c each ; 2.00 dozen. 


\section{PEONIES}

\section{THE SUPERB PERENNIAL}

Peonies will grow any where an apple tree will, being hardy and long lived. You, perhaps, possess a plant or two that grew in grandmother's garden years ago. It is the superior perennial and with the new varieties being offered you will admit there is nothing that can surpass it in beauty and charm. Investing in them is really buying a "pleasure bond" for you will "clip coupons" of beauty and pleasure for many years. Buy the good ones, they may cost more but they are worth it.

Plaliting-Planted in the shade or in the roots of trees it is a failure. Select a deep rich soil, sunny exposure and plant them just covering the eyes of the plant two inches, not more. Deep planting and shaded locations are the reasons why so many plants fail to bloom. Allow plenty of room to develop and three to four feet apart is not too much.

Fertilizing-You have been previously advised to apply manure in the winter. This is not the best practice for peonies, but rather put it on in the growing season. Be careful how you use fresh manure but try to apply well rotted or compost is better still. Bone meal, too, gives fine results.

Edulis Superba. 7.6. (Lemon, 1834)-Dark pink, even color; large, loose, flat crown. when fully open. Very fragrant; upright growth; early bloomer. One of the best commercial Peonies. There is much confusion over this variety being sold under twenty or more different names. $50 \mathrm{c}$ each; $\$ 5.50$ dozen.

Officinalis Rubra fl. pl.-Rich deep crimson; the great Decoration Day Peony. 50c each; $\$ 5.50$ dozen.

Felix Crousse 8.4. (Crousse, 1881)-Very brilliant red. Medium to large, globular, typical bomb shape; fragrant; strong growth. Stems rather weak. Midseason. $75 \mathrm{c}$ each; $\$ 8.00$ dozen.

Festiva Maxima. 9.3. (Miellez, 1851)-Paper-white, crimson markings in center. Very large and full, rose type; very tall, strong growth. Early. 50c each; $\$ 5.50$ dozen.

SFecial-Pink, Red, White. 3 for $\$ 1.00$.

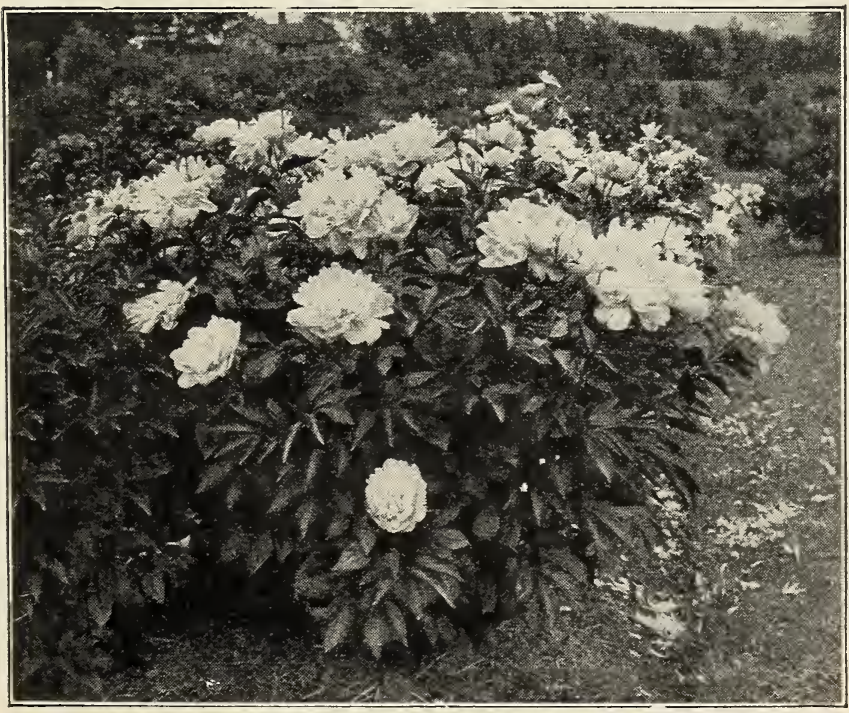

Festiva Maxima Peonies. 


\section{CANNAS}

\section{We List Only A Few Kinds That We Have, After Years of Study, Found To Be the Best}

For bedding no other plants will give the same satisfactory results. They should be planted in rich garden soil, at the end of May, when danger of frost is past. Their tropical foliage is effective, and the large flower-spikes are always a mass of bloom from early July until frost. Strong roots.

Our plants are well packed in wet moss assuring you they will arrive in good condition.

Niagara-3 feet, deep crimson, irregular, wide golden border, green foliage. $25 \mathrm{c}$ each or $\$ 2.00$ dozen.

City of Portland-Green foliage, deep pink. Our best pink. $25 \mathrm{c}$ each or $\$ 2.00$ dozen.

David Harum- $3 \mathrm{t} / 2$ feet, wine-red, dappled crimson. Bronze foliage. 30c each; $\$ 2.00$ dozen.

King Humbert-In this grand Italian Canna we have a combination of the highest type of flower with the finest bronze foliage. Its flowers, which under ordinary cultivation will measure six inches in diameter and which are produced in heavy trusses of gigantic size, are of a brilliant orange-scarlet, with bright red markings, while the foliage is broad and massive and of, a rich coppery bronze with brownish green markings. 30c each; $\$ 2.00$ dozen.

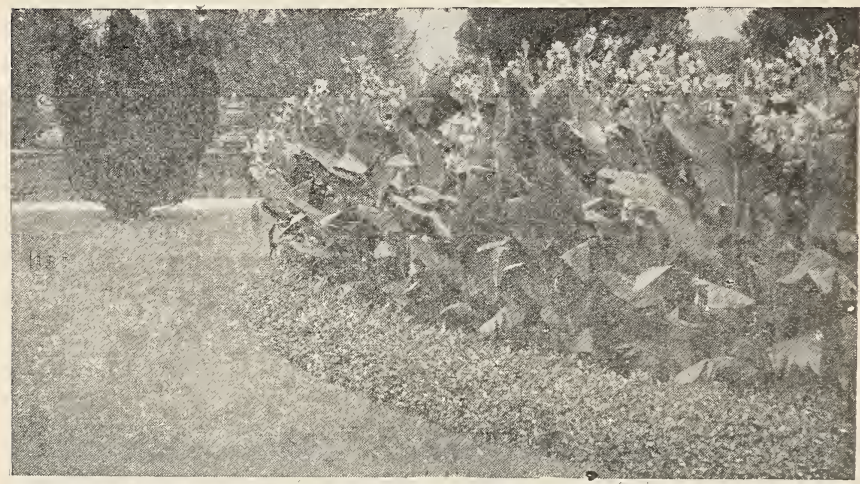

Wintzer's Colossal Canna.

Fiery Cross-Very large flower heads of vivid scarlet, shading to crimson; foliage lustrous blue-green. Five feet. $30 \mathrm{c}$ each; $\$ 2.00$ dozen.

Prince Wied-3 feet. Foliage dark green. Flowers of extra size, borne in massive clusters and of a fiery, velvety, blood red. One of the best dwarfed Cannas. 40c each; $\$ 3.00$ dozen.

Shenandoah-Bronze foliage; salmon-pink. 30c each; $\$ 2.00$ dozen.

Wintzer's Colossal-5 feet. Immense, vivid scarlet flowers. An early, persistent bloomer. The largest flowering Cana in existence. Green foliage. 30c each; $\$ 2.00$ dozen.

Yellow King Humbert-A sport of that most popular of all Cannas, King Humbert, producing large and most beautiful shades of yellow, lightly spotted red, with green foliage; five and six clusters of flowers at a time. 30c each; $\$ 2.00$ dozen.

VEGETABLE AND FLOWER PLANTS IN SEASON

Your inquiries will have our immediate attention. 


\section{DAHLIAS}

All stock here listed in strong divisions.

\section{CACTUS AND HYBRID CACTUS}

\section{Dahlia Culture}

Dahlias will succeed in any soil which will grow Corı or Potatoes, but where a choice can be made, it is best to select one rather light, well-drained and moderately rich. Before digging or plowing put on well rotted barnyard manure 2 to 3 inches deep and thoroughly incorporate it with the soil. If that is not available use Henderson's Garden Fertilizer, which can be put in the place where the Dahlia is to be planted, mixing it thoroughly with the soil, a good handful being sufficient for each. Dig a place wide enough to receive the root spread out flat and deep enough to have the crown 6 inches below the surface. Replace the soil and firm moderately.

When roots cannot be planted immediately upon arrival, they should be unpacked and stored in a cellar where the temperature is about 55 degrees. Watch them carefully and if they show signs of shriveling, cover them completely with several thicknesses of newspaper, sprinkling the papers after they are on the pile. If they show premature growth, it is evident that there is too much moisture and means should be taken to reduce it.

Attraction-Imagine a beautiful glistening lavender flower six to eight inches in diameter, of cactus type, on a stem of anywhere from three to four feet. The flowers stand erect, never looking downward, full and deep to the center, petals stiff and yet dainty, foliage a beautiful bright green. All stems run out into perfect blooms. No superfluous wood. This is what you have in "Attraction." As to keeping qualities it is unsurpassed. And mind we cut from fifteen to twenty perfect flowers to the plant. $75 \mathrm{c}$ each; $\$ 8.00$ dozen.

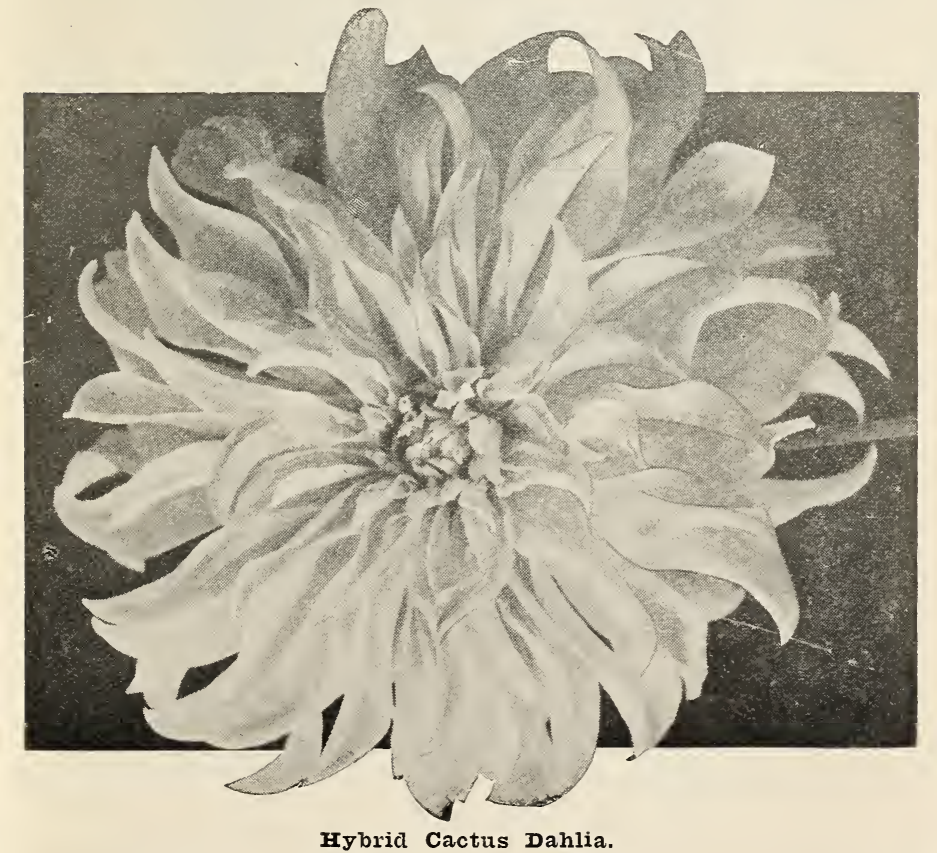




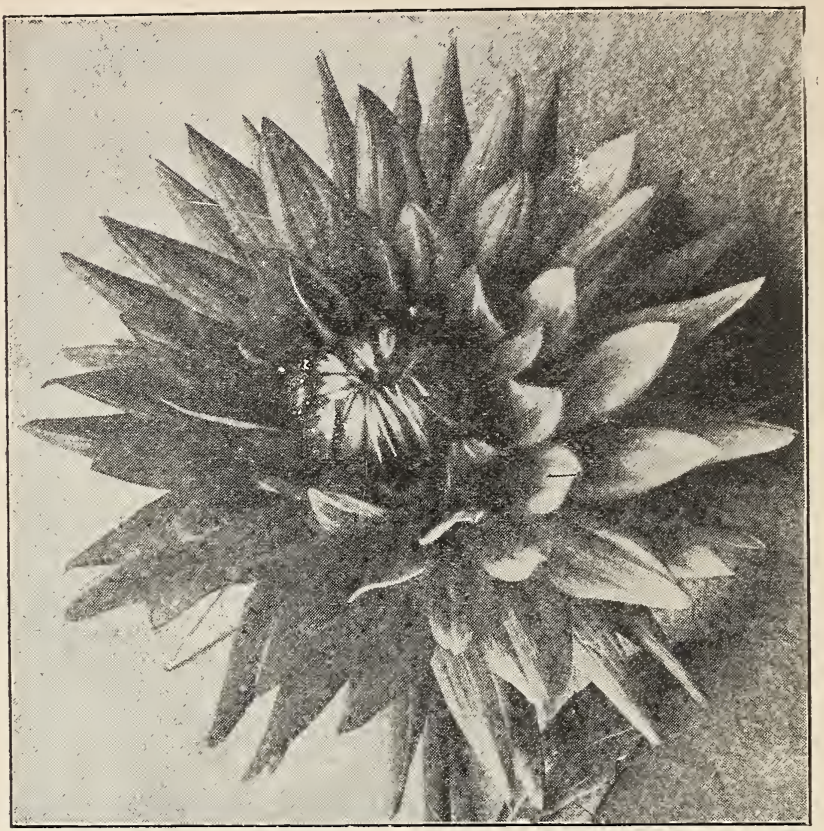

\section{Cactus Dahlia.}

F. W. Fellows-Flowers of immense size. Composed of numerous long narrow incurved petals of a lively orange scarlet. This is one of the largest and finest Autumn shade varieties. Should be in every collection. 50c each; $\$ 5.00$ dozen.

Gay Paree-Golden bronze with a faint suffusion of nasturtium red. $75 \mathrm{c}$ each; $\$ 8.00$ dozen.

Kalif-Vivid turkey red. $75 \mathrm{c}$ each; $\$ 8.00$ dozen.

Lawine-White with slight suggestion of lavender, good cut flower. 25c each; $\$ 2.50$ dozen.

Marie Doucett-Light pink. 25c each; $\$ 2.50$ dozen.

Mrs. Edua Spencer-An exceptionally fine variety for all purposes, large size, fine form and above all, a free bloomer, on long erect stems. Color silvery lilac, shading to bright orchid pink. 75 c each; $\$ 8.00$ dozen.

Mrs. Leo Niessen-Gorgeous autumn shades, yellow at base suffused and tipped a rich bronzy red. $75 \mathrm{c}$ each; $\$ 8.00$ dozen.

Mt. Shasta-Light flesh pink. $\$ 1.00$ each; $\$ 10.50$ dozen.

Rheinischer Frohsinn-A most distinct and refined variety. The flowers are large, of splendid form; the long, incurving petals are white at the base, but at about one-half their length they become suffused with and change to a luminous carmine rose. $\$ 1.00$ each; $\$ 10.50$ dozen. 
Sunset Glow-It is larger than Red Cross and better color; it is always perfect in form and will produce several times as many flowers carried on its splendid stem. The color is yellow at base of petal, outer part overlaid flame scarlet, tipped yellow. The plant is one of the very first to bloom, of medium height, 3 to 4 feet and branching habit. It is an extremely profuse bloomer and every flower is perfect. As it is larger and better colored than Red Cross, it is not only the best of this type for garden and commercial cut flowers, but a splendid exhibition bloom. 50c each; $\$ 5.00$ dozen.

Washiugton City-Snow white, of beautiful form and borne on long stems. The flowers are of enormous size. $\$ 1.00$ each; $\$ 10.50$ dozen.

Wodan-Old gold at center, shading to a salmon rose. This variety is in a class by itself, in-so-far as it is an extremely vigorous, almost rampant, grower, producing the big flowers profusely on very long stems. One of the best. 50c each; $\$ 5.00$ dozen.

Yellow King-One of the largest of all cactus dahlias, being of gigantic size and of the finest new cactus. Color light yellow, tinting to cream at the tips, giving it a most pleasing effect. The immense flowers are borne on long, stiff but slender stems. 50c each; $\$ 5.00$ dozen.

\section{DECORATIVE DAHLIAS}

Azalea-Large yellow, shaded salmon, very good. Large. $\$ 1.00$ each; $\$ 10.50$ dozen.

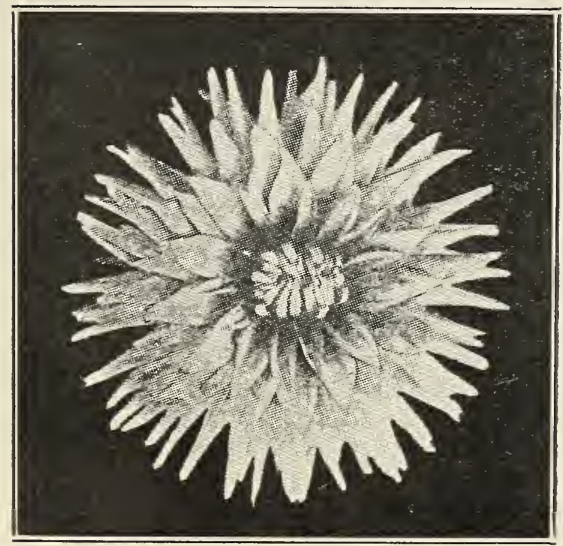

Decorative Dahlia.

Bonnie Brae-Cream shaded blush pink, very large. $\$ 1.00$ each; $\$ 10.50$ dozen.

Etendard De Lyon-Large flower. Prolific and free. 50c each; $\$ 5.00$ dozen.

Hocksai-Red and yellow, a beauty. $\$ 1.00$ each; $\$ 10.50$ dozen.

Hortulanus Fiet-Rich salmon pink. $\$ 1.00$ each; $\$ 10.50$ dozen.

Insulinde-Rich golden bronze, a beauty. $\$ 1.25$ each; $\$ 12.50$ dozen. 
Jersey Beauty-Hubbard wrote: "When a man builds a better house or makes a better mouse trap than his neighbor the world will make a beaten path to his door." Jersey Beauty has its beaten path to its door. It needs no further introduction. $\$ 2.50$ each.

La Mascotte-Entirely distinct in formation and coloring. The face of the petals is silvery pink while the reverse is reddish violet, the petals being quilled on first opening, the twotoned effect produced is very novel and pleasing. The flowers are of medium size and are produced in great profusion. \$1.00 each; $\$ 10.50$ dozen.

L. Kramer Peacock-The ideal white for garden or cutting. The flowers are of good size, perfect form, pure white and of great substance keeping a long time after being cut. The plant is a very robust grower of sturdy, branching habit, and an extremely early, profuse and continuous bloomer. 25c each; $\$ 2.50$ dozen.

Marjorie Castleton-Pink, 25c each; $\$ 2.50 \mathrm{doz}$.

Mina Burgle-This splendid variety was raised by Burgle, gardener at the Mare Island Navy Yard. Color rich cardinal red. It is of fine form. The plant is a strong, vigorous grower, producing freely on long, stiff stems. 5 feet. We offer a select strain of roots. 25c each; $\$ 2.50$ dozen.

Mrs. Carl Salbach-Fine pink, long stems ideal cut flower. $\$ 1.00$ each; $\$ 10.50$ dozen.

Mrs. Hugo Kind-A large flower that is held on long, stiff stems. Of a velvety red and of the most attractive shade. Different than most reds. Petals are irregular and of the most pleasing form. We had this on exhibition at the Philadelphia Florist Club. A vase of twenty-four on stems four foot long. They were not disbudded and showed the few side buds apparant. The leaves are a dark velvety green. A wonderful keeper. It is the first red to attract attention with visitors. $\$ 1.50$ each; $\$ 15.00$ dozen.

Mrs. I. de Ver War.er (Marean)-Orchid pink, very large, extra stem, strong grower, free bloomer, very satisfactory. $\$ 1.25$ each; $\$ 12.50$ dozen.

Nialide-In the early part of season it is a decorative. Later a beautiful pacony type. We are often asked why such a beautiful flower is not more popular. Probably due to the fact that it has not been tried out; and owing to the limited stock. 50c each; $\$ 5.50$ dozen.

Patrick O'Mara-This sensational new decorative variety was awarded a Gold Medal by the American Dahlia Society, as the best Autumn shade variety in existence. The color is an unusually soft and pleasing shade of orange-buff, slightly tinged with Neyron rose. It is very large, 7 to 9 inches in diameter, and borne on long strong erect stems. It is a strong vigorous grower and free bloomer. The giant flowers are well formed, while the outer petals are most pleasingly irregular. $75 \mathrm{c}$ each; $\$ 8.00$ dozen.

Porthos (called Blue Porthos)-Purple shading to lavender. 50c each; $\$ 5.50$ dozen.

Rosa Nell-Deep rose very large and fine. $\$ 1.25$ each; $\$ 12.50$ dozen. 


\section{SHOW OR BALL DAHLIAS}

Gold Medal (A Rare Variety)-Kinds Gold Medal. A large bronze of a brilliant shade. $75 \mathrm{c}$ each; $\$ 8.00$ dozen.

Vivian-Old rose and white. $25 \mathrm{c}$ each; $\$ 2.50$ dozen.

Wagner-Probably the largest show dahlia in our collection. Immense flower of a chrome yellow shading deeper at ends. A prize winner for size. $50 \mathrm{c}$ each; $\$ 5.50$ dozen.

Libel-Plum color. 25c each; $\$ 2.50$ dozen.

Yellow Colloss-Yellow. 25c each; $\$ 2.50$ dozen.

Beryel-Red. 25c each; $\$ 2.50$ dozen.

J. Harrison Dick-Bronze. 25c each; $\$ 2.50$ dozen.

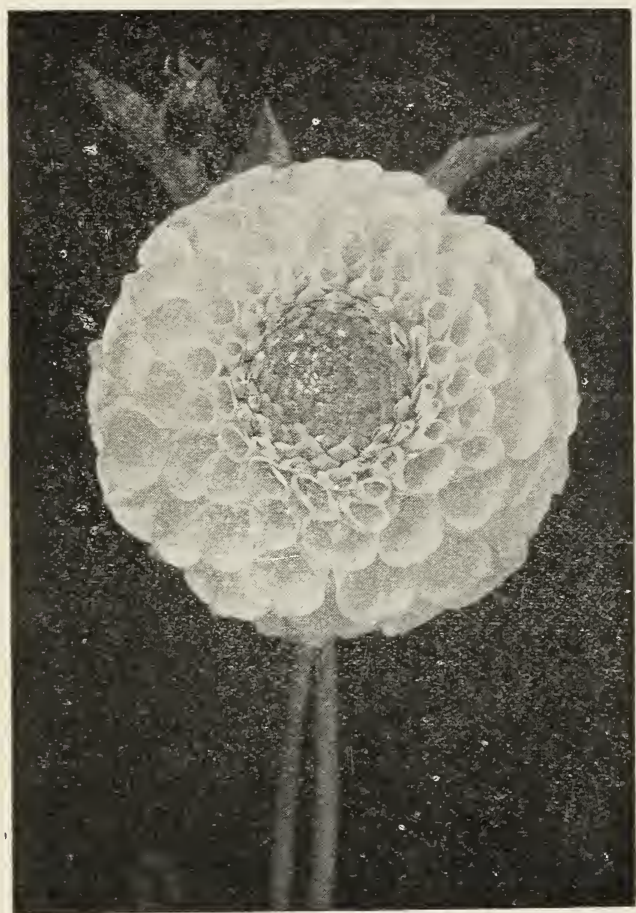

Show Dahlia.

COLLARETTE DAHLIAS

Mixed colors. 25c each; $\$ 2.50$ dozen.

$\diamond$

\section{SPECIAL OFFER}

As there are many people who care little for special sorts, we offer our selection of good varieties, selection to be made at the time order is filled, of good contrasting colors and sorts.

Price field-grown roots $\$ 1.50$ dozen; $\$ 10.00$ hundred. 


\section{GLADIOLUS}

\section{GROW GLORIOUS GLADS}

All Bulbs Listed $1 \mathrm{I} / 2$ inch Up.

Notes on the Culture of Gladiolus

The Gladiolus is a bulbous p: nt, that is, it is perpetuated by a "bulb" (botanically a "corm ') which form underground between the plant and its roots. When top-growth is developed it produces above it a new bulb to which it transfers its functions of storing up in embryo and holding in reserve the next year's roots, foliage and flowers. The new bulb after ripening off is taken up and stored away like a Potato for the next season's planting, thus continuing the annual cycle of the parent Gladiolus bulb.

The bulbs may be planted (top up) as early in the spring as the ground is fit to work. In the latitude of New York those planted in April will commence blooming in July, and by successive plantings every two weeks into the middle of the summer, a continuous succession of flowers may be enjoyed until frost. If the weather and ground is very dry, water liberally, particularly when the Gladiolus are developing their buds and flowers.

The bulbs should be planted from 2 to 4 inches deep; in light soils 4 inches deep, in heavy soils 2 inches, in medium heavy soils 3 inches deep. In groups or beds the bulbs should be planted 4 to 6 inches apart. A good way to secure a long season of bloom in a bed is to plant the bulbs 8 inches apart and then 2 weeks later fill in between with another lot of bulbs. If grown in rows the single rows should be 12 inches apart or in double rows 18 inches apart.

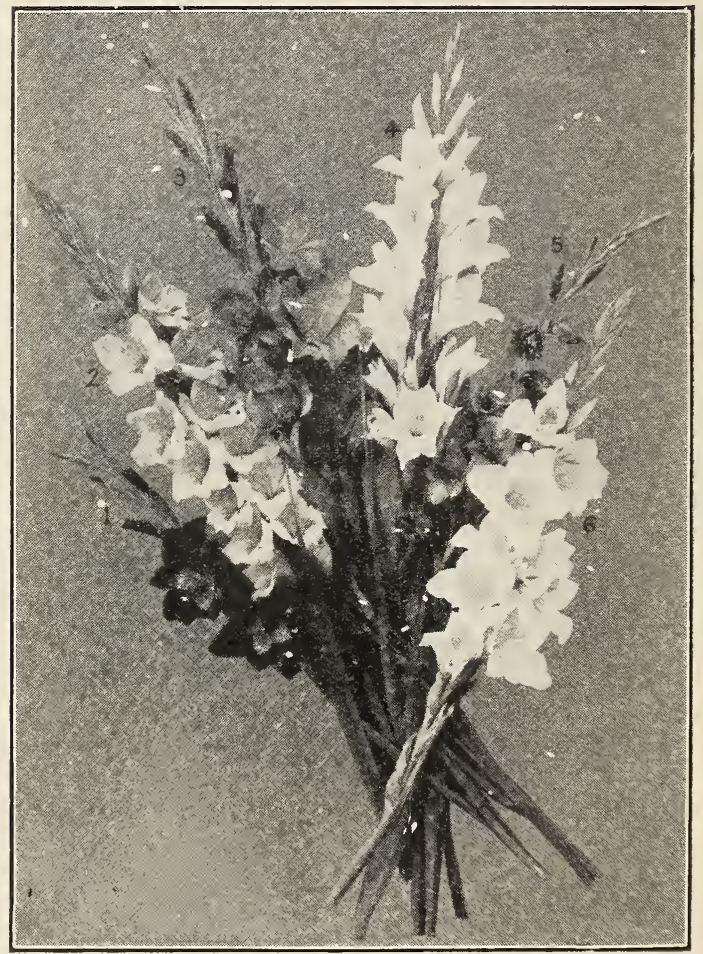

Grown from Our Mixed Gladioli Bulbs. 


\section{MOST POPULAR OF ALL SUMMER FLOWERING BULBOUS PLANTS}

\section{Rare and Beautiful Varieties}

America-Ch. Childs. Delicate lavender-pink flowers of large size, borne on strong stems, and well placed; splendid habit; still very popular as a cut flower variety. 60c dozen; $\$ 4.00$ hundred.

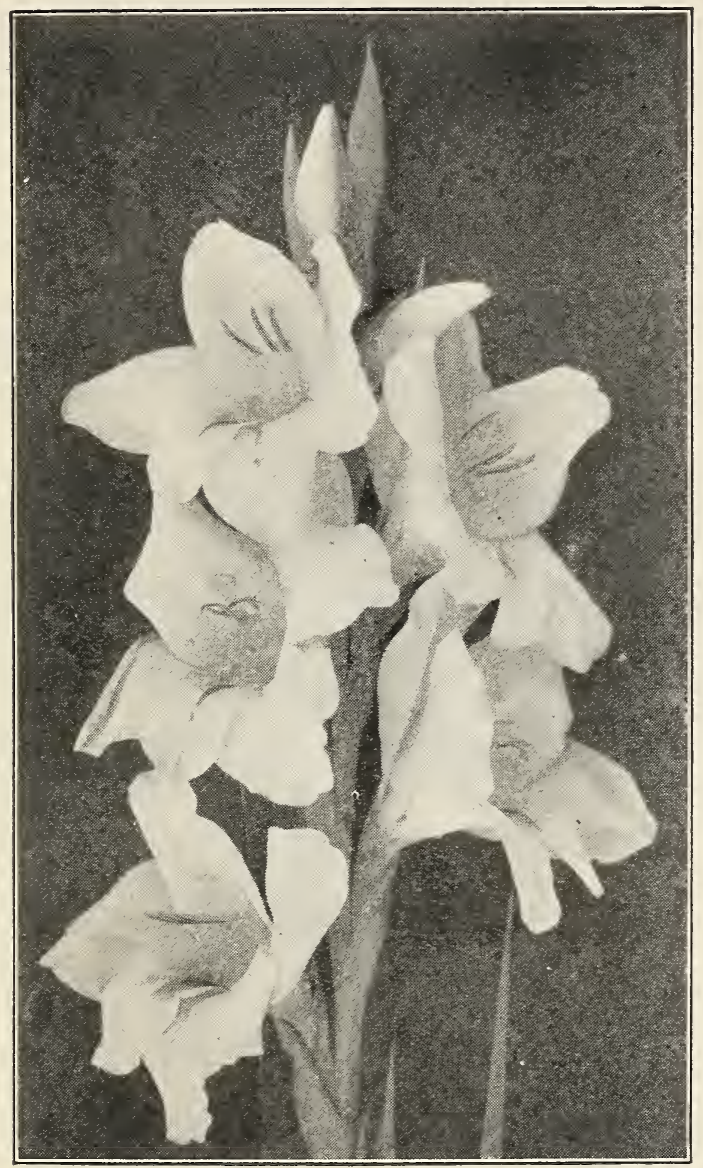

America, Gladioli.

Halley (Lem)-The predominating color of these flowers is delicate salmon-pink with a slight roseate tinge. $75 \mathrm{c}$ dozen; $\$ 5.00$ hundred.

Herada-Blooms of immense size on tall straight spikes. Massive in every way. The large blooms are pure mauve, glistening and clear, with deeper markings in throat. $\$ 1.00$ dozen; $\$ 7.50$ hundred.

Le Marechal Foch-Light pink; extra large flower. $\$ 1.00$ dozen; $\$ 7.50$ hundred.

Mrs. Francis King-Nanc. Coblentz. Light scarlet of pleasing shade. $75 \mathrm{c}$ dozen; $\$ 5.00$ hundred. 
Myra (Pr.)-New giant-flowered Primulinus Hybrid, deep salmon over yellow ground; yellow throat, pink lines. Tall slender stem. Exquisitely showy. $\$ 1.00$ dozen; $\$ 7.50$ hundred.

Gretchen Zang-The color is rose pink, blending into scarlet on lower petals. Large blooms of fine substance. $75 \mathrm{c}$ dozen; $\$ 5.00$ hundred.

Crimson Glow-The flowers of this vivid scarlet red Gladiolus when well grown are fully twice the size of that shown. They are produced on full, long spikes and the flowers develop wide open. An exhibition and garden variety par excellence. $\$ 1.00$ dozen; $\$ 7.50$ hundred.

Evelyn Kirtland (Austin)-The flowers of strong substance, beautiful shade of rosy pink, darker at the edges, fading to shell-pink at the center with brilliant scarlet blotches on lower petals, the entire flower showing a glistening, sparkling lustre. Very tall spike. Extra fine form and color. $75 \mathrm{c}$ dozen; $\$ 5.00$ hundred.

Mrs. Wyaat-A clear wine-red of most pleasing color. $75 \mathrm{c}$ dozen; $\$ 5.00$ hundred.

Mrs. Frank Pendleton (Lem. Kund)-The flowers are very large and well expanded, of a lovely flushed salmon-pink with brilliant carmine, or deep blood-red blotches in the throat, presenting a vivid contrast of orchid-like attractiveness. $75 \mathrm{c}$ doz.; $\$ 5.00$ hundred.

Peace (Gand Groff)-Flowers are large, of good form, correctly placed on a heavy, straight spike. Beautiful white, with pale lilac feathering on interior petals. $75 \mathrm{c}$ dozen; $\$ 5.00$ hundred.

Panama (Ch. Banning)-A seedling of America which resembles the parent variety in every way except that it is a much deeper pink. $75 \mathrm{c}$ dozen; $\$ 5.00$ hundred.

Schwaben (Pfitzer)-Delicate pale yellow, dark blotch in center. 75c dozen; $\$ 5.00$ hundred.

Special Mixture (Popular Mixed)-Containing an assortment of our best varieties. All No. 1 size $1 \frac{1}{4} / 4$ inch bulbs. $50 \mathrm{c}$ dozen; $\$ 3.50$ hundred.

\section{BOXWOOD}

\section{BUXUS SEMPERVIRENS}

15-inch $\$ 1.50$

18-inch

Sheared Globes 18-inch

Sheared Globes 24-inch

Sheared Pyramid 18-inch ……..................................................... 4.00

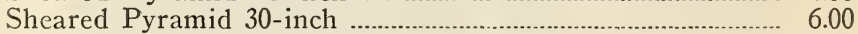

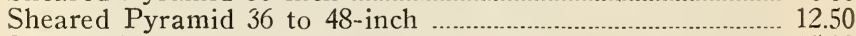

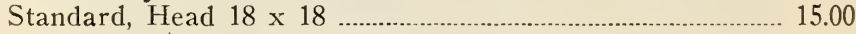

\section{BUXUS SUUFFUTICOSA}

Edging lants much used for edging borders, beds or walks or for window boxes.

This Suffruticosa Box is the variety used by The Father of Our Country in edging the walks at Mount Vernon.

6 to 8 -inch

8 to 10 -inch

$\$ 40.00$ hundred

12-inch 75.00 hundred 100.00 hundred

\section{HEDGE PLANTS}

Buxus Suffruticosa, 7-inch

Buxus Sempervirens, 10-inch …............................... 25.00 hundred

These plants are not as well furnished as stock quoted above. Not as broad and not sheared as close. Very nice plants where one wishes an inexpensive hedge. 


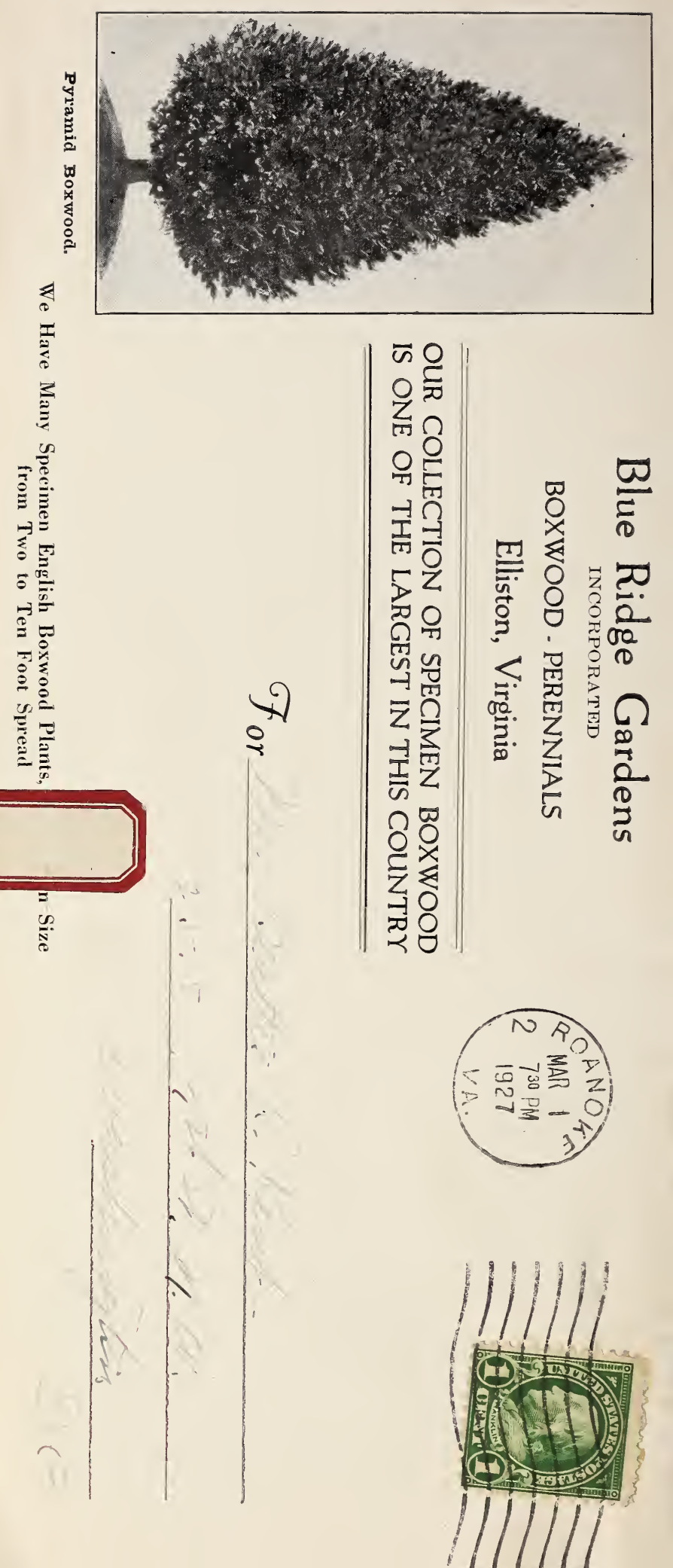

